\title{
Study of the bryological flora at the archaeological site of Chellah, Morocco
}

\author{
Meriem Elharech ${ }^{1}$, Meriem Benharbit ${ }^{3 *}$, Najib Magri ${ }^{4}$, Oumaima Benharbit ${ }^{5}$, Lahcen \\ Zidane $^{2}$, Allal Douira ${ }^{1}$, Nadia Belahbib ${ }^{1}$, Jamila Dahmani ${ }^{1}$
}

\author{
${ }^{1}$ Laboratory of Botany, Biotechnology and Plant Protection, Faculty of Science, Ibn Tofail University, BP 133, Kénitra \\ 14000, Morocco \\ ${ }^{2}$ Laboratory of Biodiversity and Plant Resources, Faculty of Science, Ibn Tofail University, BP 133, Kénitra 14000, Morocco \\ ${ }^{3}$ National Institute of Archaeology and Heritage Sciences, Rabat, Morocco \\ ${ }^{4}$ Forest Research Center, High Commission for Water, Forests and Desertification Control, Avenue Omar Ibn El Khattab, BP \\ 763 , Rabat-Agdal, 10050, Morocco \\ ${ }^{5}$ Laboratory of Biochemistry, Biotechnology, Health and Environment
}

\begin{abstract}
The Chellah archaeological site in Rabat, listed as a cultural asset since 2012 on UNESCO's World Heritage List, is subject to significant biodeterioration. The aim of this study is to identify the bryophytes that have an important impact on the destruction of the substrate. For this purpose, three prospectionswere carried out in autumn 2014, spring 2015 and winter 2016. The systematic sampling carried out allowed us to identify 20 species of bryophytes belonging to 10 botanical families, of which 4are dominant with 13 species equivalent to $65 \%$ of the total. The four families are Pottiaceae, Brachyceciaceae, Funariaceae and Bryaceae; they belong to the class of Muscinae. The liverworts are represented by only 6 species, representing $30 \%$ of the total population.

Among the 20 species inventoried, 3 are newly observed in the region of Rabat: Entosthodon pulchellus (H. Philib.) Brugués; Dydimodon Fallax Hedw. and Trichostomum crispulum Bruch.

When bryophytes settle on substrates, a preliminary soilis initiated to the detriment of the quality of materials and their durability.
\end{abstract}

Keywords-Biodeterioration, bryophytes, historical site, Chellah, Morocco.

\section{INTRODUCTION}

Like other historical sites in Rabat such as the Hassan tower or the Kasbah of the Udayas, the Chellah archaeological site, a melting pot of several civilizations (Phoenician, Carthaginian, Roman and finally Islamic)is one of the highlights of the capital's history.

The site of Chellah, alsoknown as Chellah necropolisdue to its transformation into a royal necropolis by the Marinids sultans, has undergone several archaeological excavations since 1917 thatallowed uncovering the different occupations of the site (Basset H. \& Levi-
Provençal E., 1929, Basset H. \& Terrasse H., 1932, Boube J., 1966).

Regarding the state of conservation of sites, a preliminary diagnosis by Benharbit M. in 2017, identified the main factors degrading the historical monuments of Rabat, including Chellah. These are climatic, dynamic, biological and anthropic factors. Among the biological factors, Benharbit M. (2017), cite lichens, plant roots and bird droppings. Nettah et al. (2015) worked more particularly on the lichens installed on the construction stones of Chellah. They identified six encrusting species, known as important agents of biodeterioration of building materials: Aspicilia calcarea, Verrucaria nigrescens, Toninia aromatica, Verrucaria calciseda (syn.Bagliettoa calciseda), Placidum squamulosum and Lecania spadicea. With regard to weeds, 91 species have been recorded in Chellah; their presence on buildings generally indicates the presence of moisture in the joints of materials (Taleb et al., 2005). However, no investigation has yet been carried out on bryophytes, but it is agreed that these plants are pioneer plants that initiate plant succession by participating in pedogenesis; their installation on old masonry participates in their biodeterioration. The aim of this study is thus to draw up a list of bryophytes species that are in the necropolis of Chellah and to see up to what extent they take part in the biodeterioration of the substrates.

\section{MATERIAL AND METHOD}

The archaeological site of Chellah is located within Rabat at $4 \mathrm{~km}$ from the Atlantic coast; itoverhangs the Bouregreg valley and occupies an intramural area of about 7 hectares.

Carthaginian had occupied the site in the 12th century BC and Phoenician in the 6th century BC. Later, Romans settled there and founded a city,mentioned by the Greek 
astrologer and astronomer Ptolemy under the name of Sala, and a river port serving as a Mediterranean counter. The site was then deserted and given up before being again occupied by the Marinids sultans who built there a necropolis named Al-Ribat Al Mubarak. An inscription in kufic script on the front gate indicates that the work was completed in 739 after hijri(AD 1339).

The Marinids wall, which encircles the site, currently contains characteristic vestiges of the Roman city, including in particular the capitol, the forum, the thermal baths, a nymphaeum and a triumphal arch. From the

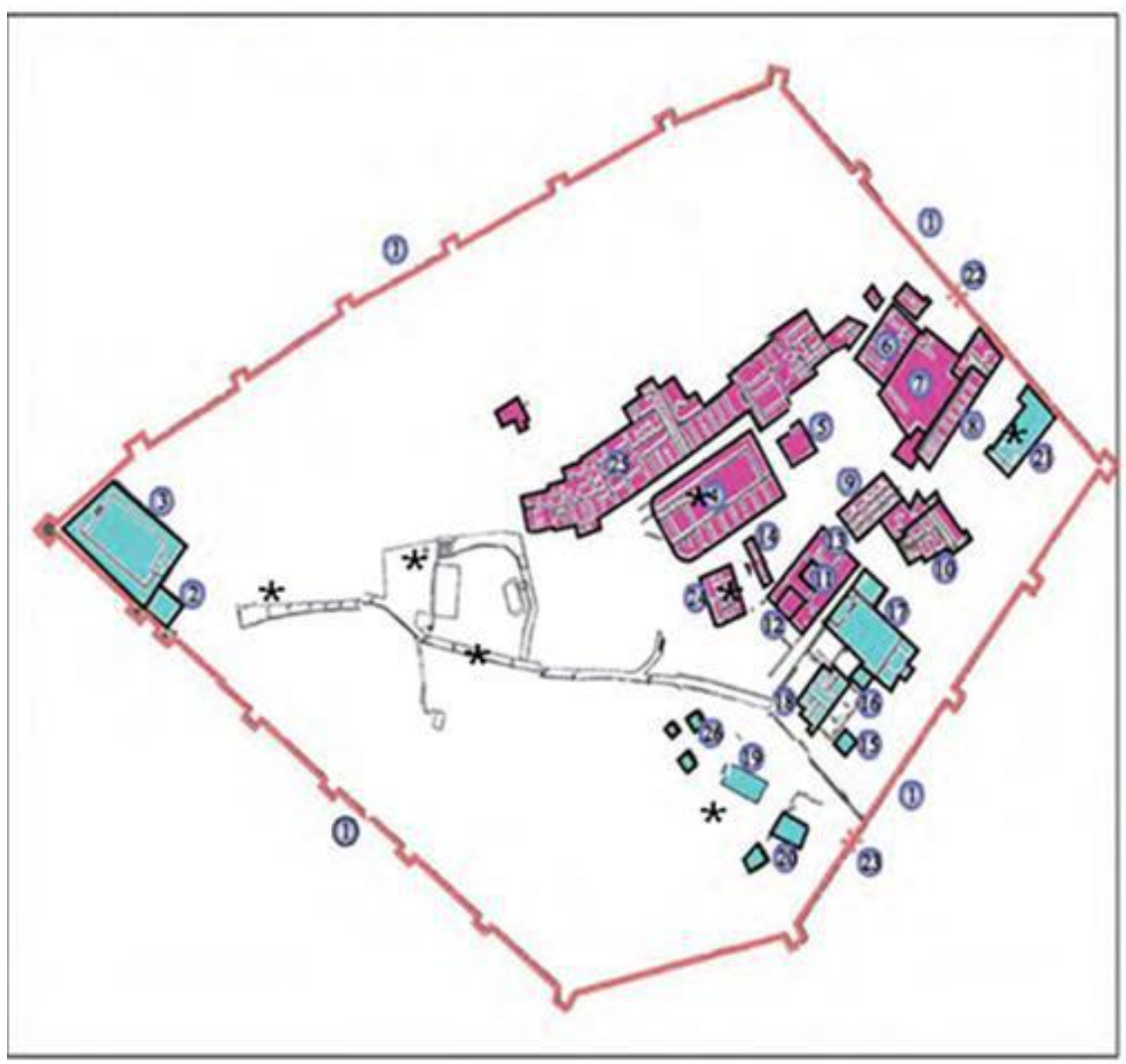

Fig.1:Location of the studied samples in the site of Chellah, Rabat

\section{METHODOLOGY}

We carried out prospections in the Chellah archaeological site during three seasons: autumn 2014, spring 2015 and winter 2016. These prospections allowed us to follow the biological cycle of the encountered bryophytes, in particular their sporulation. Further investigations were concentrated on the spring season, which is the most favorable period for observing the species with the sporophyte that is necessary for identification. The sampling is systematic and the harvest is therefore carried out at each encountered bryophyte population taking care not to pick up the entire population in order to preserve the species.

We sorted and identified the collected samples in the laboratory. The bryophytes are reviviscent plants that
Marinids occupation, there remain a mosque, a madrasah (Islamic school), a mausoleum, halls for ablutions and several funerary rooms (Fig. 1).

The site, state-owned property, is protected since november 19,1920 by the royal decree that defines as national historical monument all the complex of Chellah. Since 2012, Chellah is part of the sites of Rabat inscribed in the list of World Heritage of UNESCO as cultural asset. 
Hypnales. On the other hand, liverwortsare represented by only 6 species $(30 \%)$ grouped in 3 orders: Marchantiales, fossombroniales and sphaerocarpales.

Over the 10 encountered families, 4 clearly dominate the site (Figures 2 and 3): Potiaceae with 5 genera and 6 species, Brachytheciaceae with 3 genera and 3 species, Funariaceae and Bryaceae with 2 genera and 2 species each. These families alone account for 13 species, or $65 \%$ of the total. The other 6 families contribute only by $35 \%$.

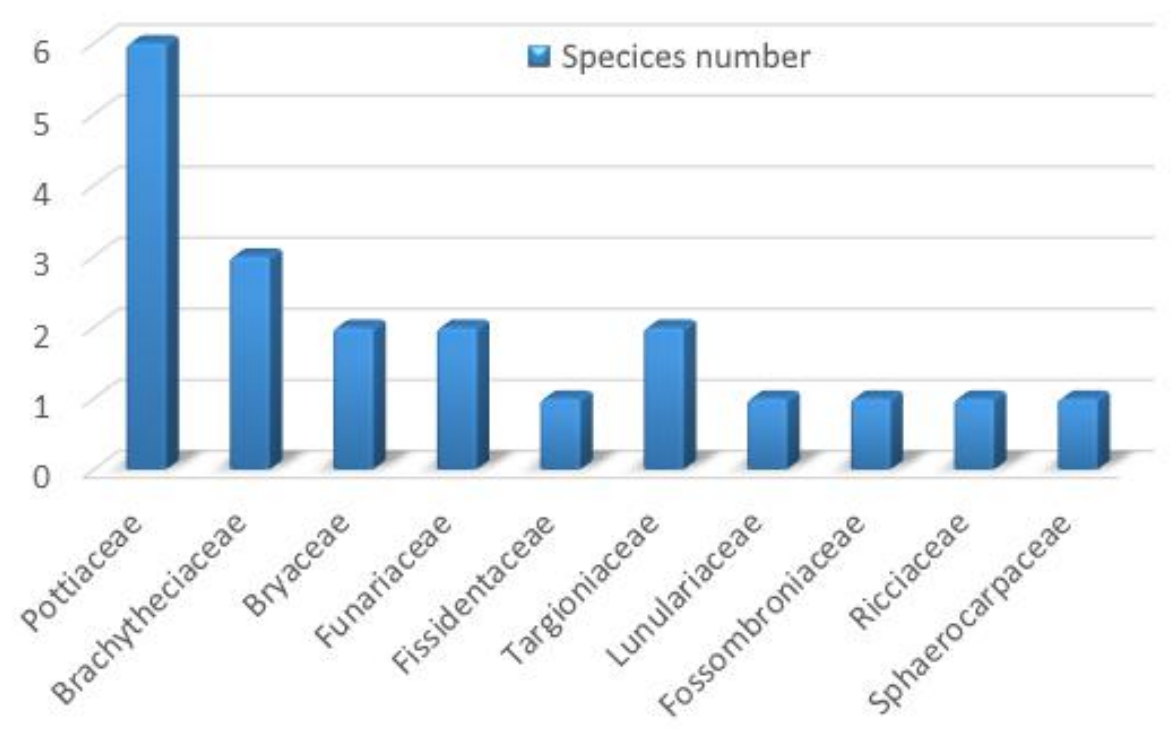

Fig.2: Specific richness per family

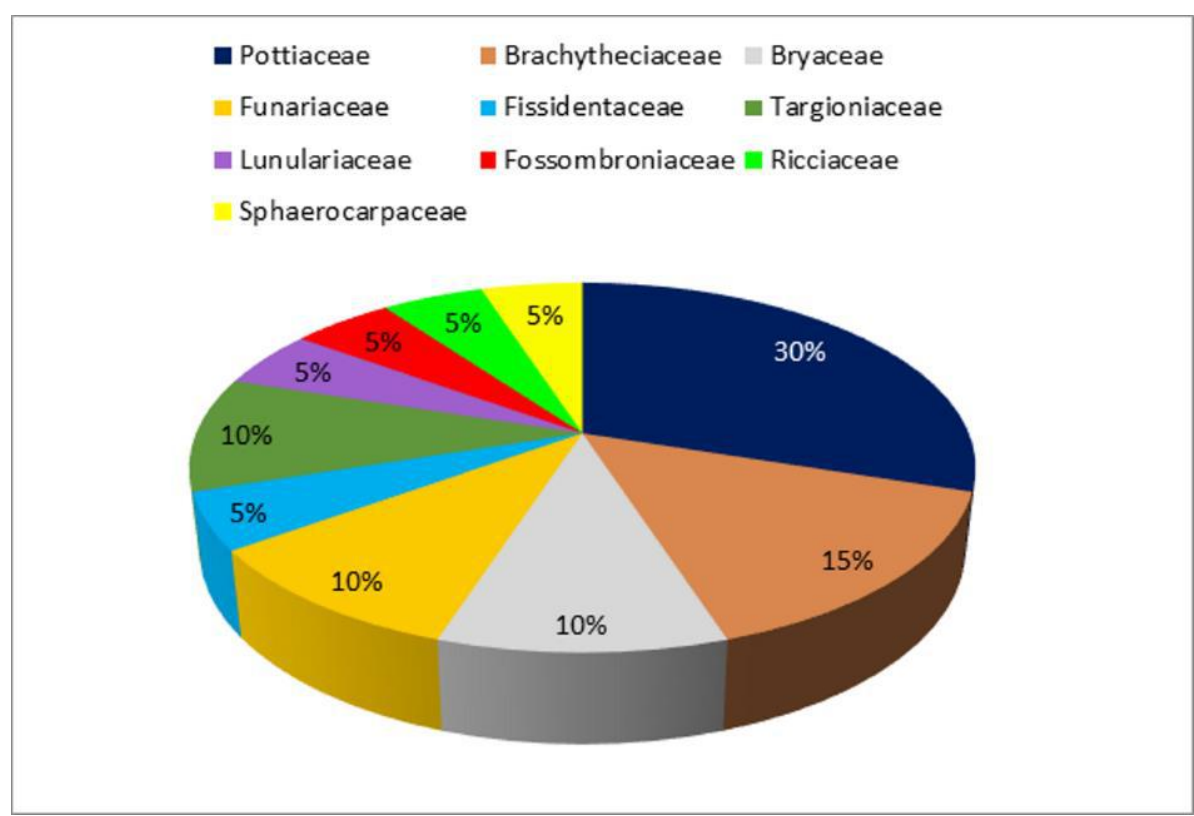

Fig.3: Spectrum of encountered families

Among the 20 inventoried species, 3 are newly described in Rabat region: Entosthodon pulchellus (H. Philib.) Brugués; Didymodon fallax (Hedw.) R.H. Zander and Trichostomum crispulum Bruch. They are illustrated in figures 4 to 6 . 


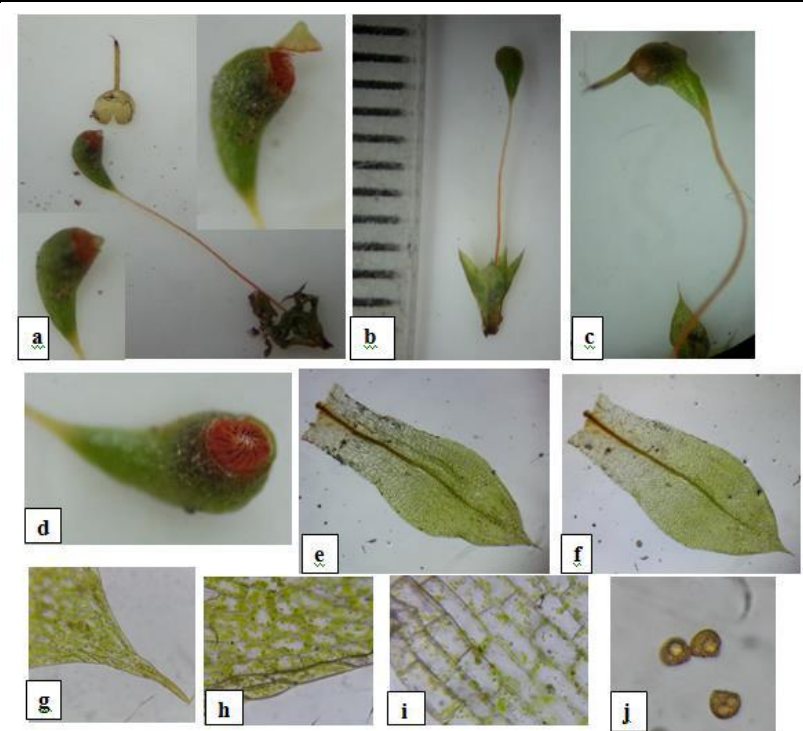

Fig.4. $a, b$ and $c$ : individual of Entosthodon pulchellus 10; $d$ : capsule showing a double peristome $x 40$; $e$ and $f$ : microscopic observations of the leaves $x 40 ; g, h$ and $i$ : respectively microscopic observations of the apical, median and basal cells of the leaves $x 400 ; j$ : microscopic observation of spores $x 400$.

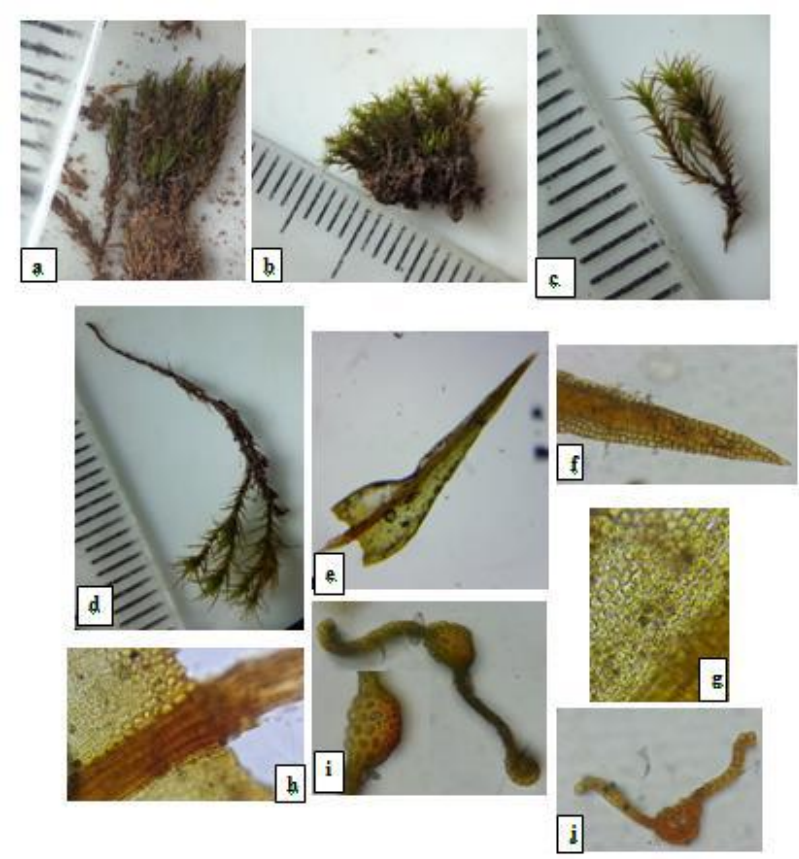

Fig.5.a: observation of a dry tuft of Didymodon fallax $x 10 ; b, c, d$ : observations of leafy stems in a wet state $x 15$; e: observation of a leaf $x 40 ; f, g$ : respectively observations of the apical, median and basal cells $x 400$; $i$ : observation of the cross sections of a leaf $x 400$.
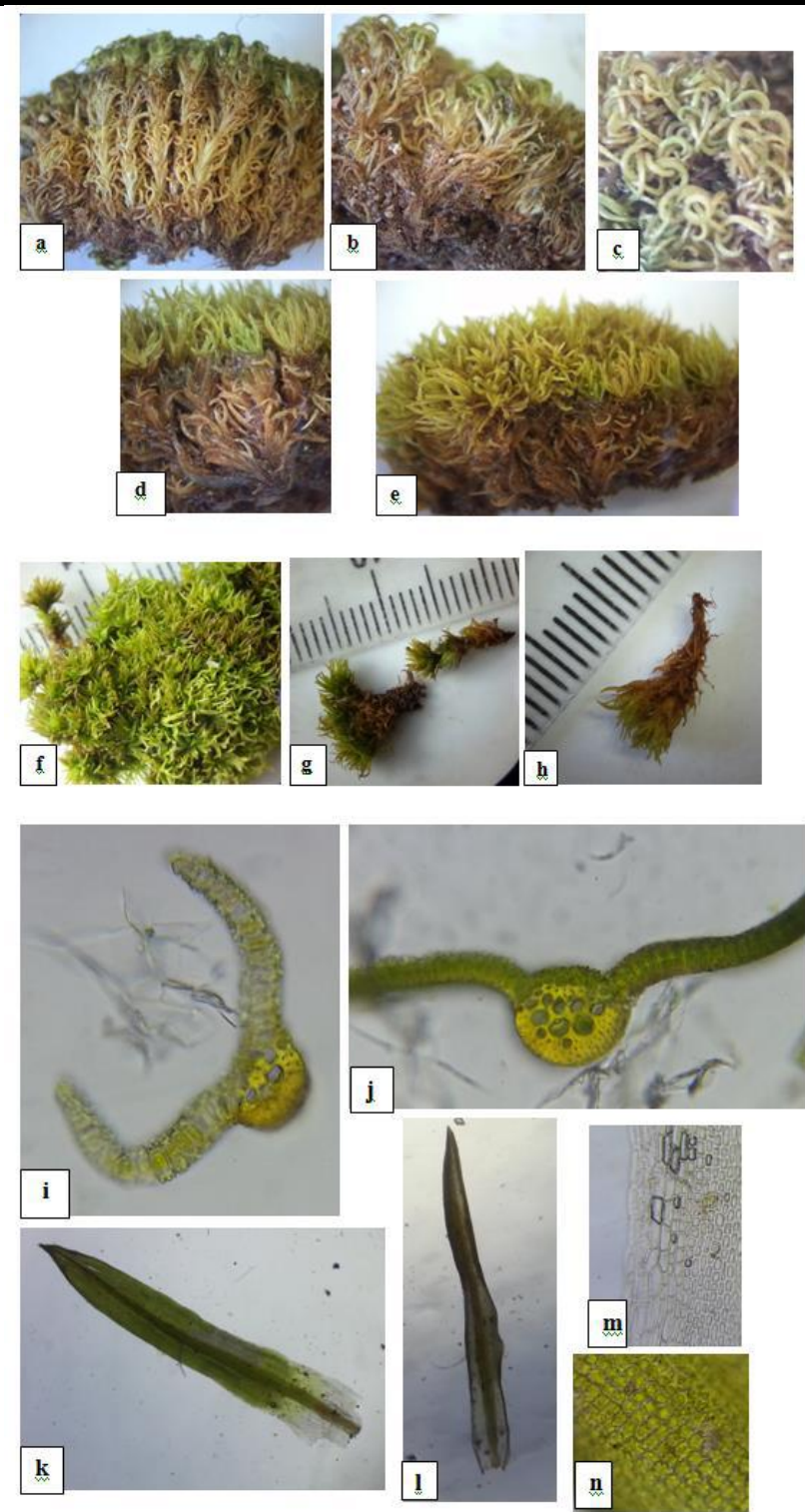

Fig.6: $a, b$ and c: Trichostomum crispulum plant in a dry state $x 15 ; d$ : plant in a wet state $x 15, e: x 10, f, g$ and $h: x$ 5; $i$ and $j$ : observation of cross sections of a leaf $x 400 ; k$ and $l$ : observation of leaves $x 40 ; m$ and $n$ : basilar cell observations with the margin $(m)$ and apical cells $(n) x$ 400

\subsection{Phyllum of Muscinae (Bryophyta)}

This phyllum contains 14 species that will be presented per family.

\subsubsection{Family of Brachytheciaceae}

Rhynchostegium megapolitanum (Bland. ex F. Weber \& D. Mohr) Schimp. (Brachythecium cardotii Winter; Eurhynchium megappolitanum (Bland ex F. Weber \& D. Mohr) Milde;Hypnum confertum var. megapolitanum (Blandow ex. H. Weber \& D. Mohr) Hampe;Hypnum megapolitanum Blandow ex F. Weber \& D. Mohr;Hypnum megapolitanum var. meridionale Schimp.;Hypnum megapolitanum var. septentrionale Boulay;Rhynchostegium megapolitanum f. julaceum 
Brizi;Rhynchostegium megapolitanum var. julaceum (Brizi) Latzel;Rhynchostegium megapolitanum subsp. meridionale (Schimp.) Giacom.;Rhynchostegium megapolitanum var. meridionale Schimp.)

In Morocco, the brachytheciaceae was reported on limestone substrates (Braun-Blanquet, 1954, Jelenc, 1955a, 1955b, 1967, Braun-Blanquet, 1954, cited by Ros et al., 1999). Elsewhere, it was reported on gravel and coastal sand by Augier (1966), and on sandy soil, or on old walls according to Boulay (1884). Smith, (2004) described it as a calcic species. In the studiedsite, it was harvested on clay-sandy soil.

Rhynchostegium megapolitanum (Bland, ex F. Weber $\& D$. Mohr) Schimp. is a lying stemmed moss harvested in a vegetative state, with unequally spaced branches of irregular length. The horizontal stem, spread out, carries branches of different thickness. The leaves are spread, drawn up, sharp, dentateand slightly concave with a relatively sharp and long pointed tip and with a simple or bifid vein that extends to about the middle of the leaf blade. The cells of the leaf blade measure $8 / 1$ and have membranes of the same thickness.

Rhynchostegiella curviseta (Brid.) Limpr. (Eurhynchium curvisetum (Brid.) Delogne;Hypnum curvisetumBrid.;Hypnum rigidulum Bruch;Rhynchostegiella curviseta var. laeviseta (W.E. Nicholson \& Dixon) Podp.; Rhynchostegiella letourneuxii (Besch.) Broth.;Rhynchostegium curvisetum (Brid.) Schimp.;Rhynchostegium curvisetum var. fastigiatum Bott.; Rhynchostegium letourneuxii Besch.; Rhynchostegium curvisetum Schimp.).

It has been reported on limestone rocks of streams and on wet walls (Hamada et al., 2002); Which is in agreement with Augier (1966) who also observed it on calcareous stones. Smith (2004) noticed it on rocks, wet stones, top of trees, walls, streams, rivers, canals, lakes, and shady shores. At Chellah, it was harvested on limestone rocks.

Rhynchostegiella curviseta (Brid.) Limpr. is a Pleurocarpus moss with a creeping stem, irregularly ramified by more or less drawn up branches from 5 to 10 $\mathrm{mm}$ length and unequally spaced. The drawn up leaves,lanceolate, narrow, and gradually narrowed leaves in the upper half are weakly toothed and have a vein that reaches the middle of the leafblade. The middle limb cells are more than 10 fold longer than broad. The silk is red, rough and slightly curved in $\mathrm{S}$. The actinomorphic capsule is more or less inclined.

Scorpiurium circinatum(Bruch) M. Fleisch. \& Loeske (Hypnum circinatumBrid.;Scorpiurium circinatum (Brid.) Fleisch. \& Loeske;Eurhynchium circinatum (Brid.) Schimp.;Alsia circinata (Brid.) Kindb. illeg. hom.;Hypnum leskea Grev.;Hypnum mediterraneum Sendtn.;Hypnum strigosum var. circinnatum
Brid.;Rhynchostegium circinatum (Bruch) De Not.; Scorpiurium circinatum var. ruderale (Brizi) M. Fleisch. \& Loeske;Thamnium cossyrense var. melitense Bott.). It has been described as a terricole by Ros et al. (2001); It was observed on rocks and tree trunks, at an altitude ranging from 1500 to $2000 \mathrm{~m}$ a.s.l. (Maire \& Werner, 1934; Jelenc,1955a, 1967 ; Ros et al, 1990; Rauh, 1952, cited by Ros et al., 1999); like on vertical limestones and in overhang, sometimes under very shady conditions (Jiménez et al., 2002b). It has also been encountered on sand or on sunny rocks of nature rather limestone (Augier, 1966); Smith, (2004) cites very diversified substrates and insists on the fact that these substrates are not exclusively limestone. It was collected on ground and on the sunny limestone rocks of the studied site.

Scorpiurium circinatum (Bruch) M. Fleisch. \& Loeske is a Pleurocarp moss with a reeded stem with twigs in a dry state not reaching $1 \mathrm{~mm}$ wide, arched at their end. It occurs in thick tufts of about $2 \mathrm{~cm}$, olive green and faded on the surface. The leaves are oval, about $1 \mathrm{~mm}$ in length, revolved only at the base, and denticulate in the upper part of the limb. The middle limb cells are relatively short (3 to 4 out of 1). It was harvested in a vegetative state.

\subsubsection{Family of Bryaceae}

Ptychostomum capillare (Hedw.)Holyoak \& N. Pedersen(Bryum capillare Hedw.;Bryum aschersonii Müll. Hal.;Bryum capillare var. platyloma (Schwägr.) Schimp.;Bryum capillare var. rufifolium (Dixon) Podp.; Bryum capillare var. meridionale Schimp.;Bryum capillare var. macrocarpum Huebener; Bryum capillare var. tectorum Warnst.; Bryum capillare var. triste (De Not.) Limpr.;Bryum capillare var. ustulatum G. Roth.;Bryum capillare var. majus Bruch \& Schimp.illeg. nom. incl. var. prior.;Bryum capillare subsp. meridionale (Schimp.) Podp.;Bryum cochlearifolium (Brid.) Hartm.;Bryum rufifolium (Dixon) Demaret \& R. Wilczek;Bryum torquescens var. gracile Besch.;Bryum validicostatum Cardot \& Dixon; Mnium capillare (Hedw.) With.).

In Morocco, this species was found on siliceous substrates (High-Atlas) (Werner, 1932; Gattefossé, 1932); on granite (Zaïan) (Gattefossé, 1931-1932, cited by Gattefossé \& Werner, 1932) and on granitic and porphyritic rocks (Mayor, 1924). It has been reported on sandstones in Tangier; on sands in the Mamora forest near Rabat and on quartzites near Benslimane (Maire \& Werner, 1934). Outside Morocco, (Ros et al., 2000) observed it on the edges and cracks of granitic and quartzitic rocks and on peats between 2100 and $3300 \mathrm{~m}$. It was collected on the shady limestone rocks of the studied site.

Plychostomum capillare (Hedw.) Holyoak \& N. Pedersen, is a 4 cmAcrocarpus moss with a circular to 
slightly polygonal stem. The twig has a helical shape. Leaves are spatulate, twisted in the dry state, drawn up and spread apart in the wet state. They are cogged at the apex with an excurrent vein, margined on most of their length and mainly on the upper part of the limb where two rows of longer elongated cells are observed, the other cells are less elongated (2-3 of 1 at least), of hexagonallosangic shape, having tips at the ends of their major axis. The middle of the limb has a large and loose areolation with cells of 2 to 3 on 1 in general. The sporophyte is well developed with an orange smooth silk of $2.5 \mathrm{~cm}$ and a rust-colored capsule of $4 \mathrm{~mm}$, hanging with a double peristome.

Bryum radiculosum Brid (Bryum duriaei Schimp. ex Besch.;Bryum murorum (Schimp.) Berk; Bryum eurythrocarpum var. murorum Schimp;Bryum atrovirens var. radiculosum (Brid.) Wijk \& Margad.; Bryum erythrocarpum var. limbatumBerth.;Bryum erythrocarpum var. murale Wils. ex Hunt. err. pro B. erytrocarpum var. murorum Schimp.; Bryum erythrocarpum var. radiculosum (Brid.) Bruch \& Schimp.; Bryum murale Wilson ex Hunt. illeg.hom.).

In Morocco, it was observed on land in the Oued El Abid gorges at Bin ElOuidane (Mayor \& Werner, 1934, Mayor and Werner, 1932, quoted by Gattefossé \& Werner, 1932); (Jelenc, 1967, Jelenc, 1955b, cited by Ros et al., 1999); on the edges of the granitic rocks, between 2210 and $2400 \mathrm{~m}$ (Ros et al., 2000). It was first described in the Anti Atlas by Cano et al.in 2002. Elsewhere, it was reported on stony soils or on the wall mortar by Augier (1966) and Smith (2004) who considered it as a calcareous species. On the site of Chellah, it was harvested on limestone rocks.

Bryum radiculosum Brid is a yellowish-green acrocarpus moss, dioecious in compact tufts $4-10 \mathrm{~mm}$ high, with well-differentiated stem, oval-lanceolate leaves of about 2 $\mathrm{mm}$, acuminate, denticulate at apex, the brown-russet-red veinis excurrent, the limb is smooth with a narrow and tightly bounded area around the middle (cells measure 6/1 at least). This plant was harvested in a vegetative state during the three prospections.

\subsubsection{Family of Fissidentaceae}

Fissidens bryoides Hedw (Dicranum bryoides (Hedw.) Sw. (Fissidens arcticus Bryhn, hypnum bryoides Linn.).

It was seen on the walls of Rabat (Braun-Blanquet \& Maire, 1924), on non-calcareous shallow ground by Augier (1966), on slopes, along the paths, on wet stones, Boulay (1884). Smith (2004), found it on neutral to acid soils or more rarely on wood or stones in open areas. At Chellah, it was harvested on concrete and wet soil.

Fissidens bryoides Hedw (Dicranum bryoides (Hedw.) $\mathrm{Sw}$.,is a small acrocarpus moss of $1 \mathrm{~cm}$ of length, with a short, drawn up and simple stemfixed on the substrate by fine and dense rhizoids. The leaves are spread out, inserted over two rows on both sides of the stem. They are oblong to lanceolate, acute, with a dorsal blade (sheath) shorter than the limb measuring about $1 / 3$ of the length of this one and margined byvery narrow cells that are lengthened and hyaline. The cells of the limb are isodiametric and short, square almost round. The vein is simple, excurrente in a small mucron. ( $5 \mathrm{~mm}$ ). The silk is short (5 mm), red, the capsule is ellipsoidal, drawn up and green with a simple peristome made up by red teeth divided up to the middle.

\subsubsection{Family of Funariaceae}

Funariella curviseta (Schwägr.) Sérgio (Funaria curviseta (Schwägr.) Milde, Gymnostomum curvisetumSchwägr.,Physcomitrium curvisetum (Schwägr.) Bruch \& Schimp., Entosthodon curvisetus (Schwägr.) Müll. Hal.)

It was reported on limestone (Braun-Blanquet, 1954, Jelenc, 1955a, 1967, Braun-Blanquet, 1954, quoted by Ros et al., 1999); In the cracks and crevices of limestone rocks on wet sites with maritime influence. It was collected between the cracks of the limestone rocks of the studied site.

Funariella curviseta (Schwägr.) Sérgio, is a small acrocarpic moss of $5 \mathrm{~mm}$ of height, forming grass between the cracks of limestone rocks, with toothed leaves in the upper part, acuminate and without clear margin. The isolation is smooth in the upper part of the limb, is more or less translucent with rectangular cells and a vein finishing close to the top. The silk is about $2 \mathrm{~mm}$ long. The mature capsule is brown, symmetrical, pyriform, sloping at pendulum before dehiscence and darwn up at maturity with reticulated spores of $20 \mu \mathrm{m}$ in diameter. The capis well developed, swollen and has a long beak. The peristome is absent. It forms a stand in association with Targionia hypophylla in the studied site. *Entosthodon pulchellus (H. Philib.) Brugués (Funaria pulchella $\mathrm{H}$. Philib.)

It has been reported on the cracks of granitic rocks at $2100 \mathrm{~m}$ a.s.l. (Ros et al., 2000). It was observed on basic soils in meadow and between rocks, and referred to as calcicole by Smith, (2004). It was picked up on rocks and limestone groundsof the studiedsite.

Entosthodon pulchellus (H. Philib.) Brugués is an 8 to 12 $\mathrm{mm}$ acrocarpus moss, forming loose turf on moist soil, the apical leaves, being larger than the others, formoval and whole rosettes. The limb is more or less translucent and terminated in a long filiform point; theareolation is smooth in the upper part, comprises rectangular cells more or less elongated from 2 to 3 in 1 at least. The vein does not reach the top of the limb. The silk is rectilinear; the capsule is oblique, and the urn is smooth. The spores are finely papillose and are about $20 \mu \mathrm{m}$ in diameter. 
4.1.5. Family of Pottiaceae

Barbula unguiculata Hedw. (Barbula apiculata Hedw.; Barbula fastigiata Schultz; Barbula gattefossei P. de la Varde; Barbula microcarpa Schultz; Barbula obtusifolia Schultz illeg.hom.;Barbula unguiculata var. apiculata (Hedw.) Bruch \& Schimp.; Barbula unguiculataf. apiculata (Hedw.) Mönk.; Barbula unguiculataf. cuspidata (Schultz) Mönk.; Barbula unguiculata var. cuspidata (Schultz) Brid.; Barbula unguiculata var. fastigiata (Schultz) Huebener; Barbula unguiculata var. latifolia Bréb.; Barbula unguiculata var. microcarpa (Schultz) Huebener; Barbula unguiculata var. minus Hillier; Barbula unguiculataf. obtusifolia Mönk.; Barbula unguiculata var. robusta Lindb.; Bryum unguiculatum (Hedw.) With.;Dialytrichia canariensis Bryhn;Streblotrichum unguiculatum (Hedw.) Loeske.;Tortula unguiculata (Hedw.) P. Beauv. illeg. nom.)

It was seen on the edges of granitic rocks, on quartzic soils near streams (Ros et al., 2000); as well as on the bases and trunks of Quercus rotundifolia (Draper et al., 2006). It was described as a messicole by Augier (1966), which described it as a pioneer plant on clay soil and limestone sand. It was seen on very diversified substrates by Boulay, (1884), who observed it particularly on disturbed soils or on landfills. It was collected on limestone rocks and on clay-sandy soil of the studied site. Barbula unguiculata Hedw. is an acrocarpus moss of 1.5 to $2 \mathrm{~cm}$ of length. The leafed stem is about $1 \mathrm{~cm}$ of length. The basal leaves are revolved and measure 1.5 to $3 \mathrm{~mm}$, with an excurrente vein with two stereidsbands. The leaves are helically and strongly twisted in a dry state. The top of the limb is flat and obtuse and has numerous C-shaped papillae. The sporophyte is made up of a red silk and a $1.5 \mathrm{~mm}$ capsule. The spores are smooth, yellowish green and 10 to $12 \mu \mathrm{m}$ in diameter. The teeth of the peristome describe 2 to 3 spiral turns.

*Didymodon fallax (Hedw.) R.H. Zander (Barbula acuminataHedw.;Barbula

adriatica

Baumgartner;Barbula brevicaulis Schwägr.; Barbula brevifolia (Dicks. ex With.) Brid.;Barbula fallaxf. brevicaulis (Schwägr.) Podp.;Barbula fallax var. brevicaulis (Schwägr.) Huebener; Barbula fallax var. brevifolia (Dicks. ex With.) Schultz; Didymodon fallax var. adriatica (Baumgartner) Düll; Didymodon fallax var. brevifolius (Dicks. ex With.) Ochyra; Tortula fallax (Hedw.) Schrad. ex Turner;Barbula Fallax Hedw).

It has been seen on fresh rocks in a sterile state (Jahandiez, 1923); at the bottom of limestone rocks, on damp ground; on porphyritic rocks (Maire \& Werner, 1934); on limestone (Braun-Blanquet, 1954); Ros et al., 2001 describe it as a terricole species; and according to Jiménez et al., (2002b), it would develop on cracks of rock and on sandy soils. Smith, (2004) noticed that it can be present on clay-rich soils and on sand dunes at altitudes ranging from 0 to $490 \mathrm{~m}$. It was collected on clay-sandy soil of the studied site.

Didymodon fallax (Hedw.) R.H. Zander is an acrocarpusmoss harvested in a vegetative state from 1 to 3 $\mathrm{cm}$ in height; It is rust-colored. The stem is ramified, with a differentiated axial beam. Partially revolved leaves are acute and lanceolate $2-3 \mathrm{~mm}$ in length, spread-arched, more or less squarrose, in the wet state. The top of the limb is plane and acute with conical papillae that make areolation quite distinct. The base of the limb shows some rectangular and elongated cells whereas others are a little longer than the cells of the higher half of the limb, with thick membranes.

Timmiella barbuloides (Brid.) Mönk (Barbula cirrhata Arn.; Timmiella barbula Limpr illeg. nom.; Timmiella barbula var. minor Schimp. ex Luisier; Trichostomum Barbula Schwaegr. illeg. nom.; Trichostomum barbuloides Brid.).

It develops on limestone rocks (Mayor, 1924) and (Augier, 1966); at the bottom of walls and maritime cliffs of Rabat, as well as on travertines at Taza (BraunBlanquet and Maire, 1924). It has been reported on siliceous groundo wet places (Maire \& Werner, 1934); in tufa caves at Zalagh Mount near Fez and in Taza Gorges (Braun-Blanquet, 1954, Jelenc, 1955a, 1955b, 1967, Ros et al., 1990, Braun-Blanquet, ., 1999).; on clay soil, at the bottom of rocks and walls and in ravines according to Boulay, 1884. At Chellah, it was collected on limestone rocks.

Timmiella barbuloides (Brid.) Mönk, is a $3 \mathrm{~cm}$ acrocarpus moss. The tuft is of a dark green shining in the dry state. The stem, of $5 \mathrm{~mm}$, is not ramified. The sheathing leaves, involute, of hooked form in the dry state, carry on the upper face high projections each formed by a cell. The limb is largely bistratified with a veinincluding two bands of stereids. The capsule presents a rudimentary ring with a very little twisted peristome with 32 long and fine teeth.

Tortula marginata (Bruch \& Schimp.) Spruce (Barbula marginata Bruch \& Schimp.; Desmatodon meridionalis Luisier; Tortula limbata auct.).

It has been described as calcicole by Augier (1966) and has been observed on limestone rocks (Ahayoun et al., 2007). Boulay, 1884, observed it on the walls, the rocks and in the shaded and little covered places. Smith (2004),noticed it on wet and shaded basic rocks as well as on the walls of natural and artificial habitats. It was taken from the limestone rocks at Chellah.

Tortula marginata (Bruch \& Schimp.) Spruce is a $10 \mathrm{~mm}$ acrocarpusmoss. It organizes small stands with lichen in the studied site. The leafed stem is about $2 \mathrm{~mm}$ high. The leaves are very little revolved, lingulate and narrow from 
2 to $3 \mathrm{~mm}$ lenght with an excurrente vein in a rather long point. They are margined on almost all their contour by two strata of cells. The latter are more elongated and narrower than those of the rest of the limb. The areolation is papillose and opaque in the upper part of the limb, where the cells are quadrangular, almost square; it is smooth and translucent in the lower part of the limb, where the cells are rectangular and elongated. The capsule, of about $2 \mathrm{~mm}$, is without cover and contains yellowish smooth spores of $10 \mu \mathrm{m}$ in diameter.

Tortula muralis Hedw. (Barbula heribaudiiCorb.;Barbula muralis (Hedw.) Crom.;Barbula muralis var. incana Bruch \& Schimp.;Barbula muralis var. obcordata Schimp.; Barbula muralis var. rupestris Schultz; Bryum murale (Hedw.) With.;Syntrichia muralis (Hedw.) Raab;Tortula aestiva var. vulcanicola Schiffn.;Tortula muralisf. incana (Bruch \& Schimp.) Sapjegin;Tortula muralis var. incana (Bruch \& Schimp.) Wilson;Tortula muralisf. obcordata (Schimp.) Mönk.;Tortula muralis var. obcordata (Schimp.) Limpr.;Tortula muralis f. rupestris (A. Chev.) Sapjegin;Tortula muralis var. rupestris A. Chev.)

It has been reported on granite (Gattefossé, 1931-1932, quoted by Gattefossé \& Werner, 1932); On the Roman ruins of Volubilis (Braun-Blanquet, 1954, Jelenc, 1955a, 1955b, 1967, Braun-Blanquet, 1954, cited by Ros et al., 1999). Cano et al. (2002) described it for the first time in the Anti Atlas on bare soils. Its presence was also noted on the banks of the BouRegregriver; on granite; onlimestone rocks; as well as on limestone slopes (Ahayoun et al., 2007). Boulay, (1884) and Smith (2004) cite very diverse substrates such as walls, roof tiles and cracks in rocks. Smith, (2004) argues that Tortula muralis tends to prefer basic substrates and is found more rarely on acidic substrates and is more common in urban areas where it is able to resist atmospheric pollution. At Chellah, it was harvested on limestone rocks.

Tortula muralis $\mathrm{Hedw}$ is an acrocarpus moss about $2 \mathrm{~cm}$. The leaves are more or less drawn up-isolated in the wet state, contracted and twisted in the dry state, with a strong vein all along the leaf, showing in cross-section a single band of stereids, dorsal, excurrent in one hair smooth or slightly dentil, often flexuous hyaline, long; formed hyaline point, partly at least, by the vein itself. The limb is very papillose at the top, and revolute up to near the summit. The cells of the upper part of the leaf are furnished with manypapillae, they are square-subaronded, very chlorophyllian, elongated towards the middle. The basal cells are hyaline, rectangular and longer. The drawn up cylindrical capsule takes on a blackish color at maturity with a long beak opercula (1/4length of the capsule), and a cupped headdress. The peristome has completely divided teeth up to the basilar membrane; it then appears formed of 32 bristles, twisted in whorl with 1-3 turns. The spores are spherical with a smooth wall about $10 \mu \mathrm{m}$ in diameter.

Tortula muralis var. aestiva Brid. ex Hedw.(Barbula aestiva (Brid. ex Hedw.) Schultz;Barbula muralis var. aestiva (Brid. ex Hedw.) Röhl.;Tortula aestiva (Brid. ex Hedw.) P. Beauv.;Tortula muralis subsp. aestiva (Brid ex Hedw.) Meyl.).

It is a bright green plant with the same characteristics as Tortula muralis Hedw except in the shape of the leaf, which is tightly lingulate, spatulate with an excurrente vein in a yellowish green tip.

Trichostomum crispulum Bruch. (Mollia crispula (Bruch) Lindb.,Trichostomum brevifolium Sendtn. ex Müll. Hal.;Trichostomum crispulum var. acuminatum Meyl.; Trichostomum crispulum var. angustifolium Bruch \& Schimp.;Trichostomum crispulum subsp. brevifolium (Sendtn. ex Müll. Hal.) Giacom.;Trichostomum crispulum var. brevifolium (Sendtn. ex Müll. Hal.) Bruch \& Schimp.; Trichostomum crispulum var. cucullatum (Cardot ex G. Roth) Podp.; Trichostomum crispulum var. elatum Schimp.; Trichostomum crispulumf. longifolium Bouvet;Trichostomum crispulum var. pseudoweisia Schimp.; Trichostomum crispulum var. viridulum (Bruch) Dixon; Trichostomum hammerschmidii Loeske \& H.K.G. Paul; Trichostomum viridulum Bruch)

It develops on the ground and in the cracks at the base of moist granitic rocks (Ros et al., 2000). It has been described as a pioneer on limestone rocks, on gravelly soil and on coastal dunes by Augier (1966). Boulay, (1884), notes its presence on the sandy or marly soil of the hills, in the hollows of the rocks, on the old walls and on the fixed sands of the old dunes. According to Smith 2004, it is found in shaded or exposed basic habitats, on the ground, rocks, rocky banks, cliffs, old wall mortar, and sandy dunes. It was collected on limestone rocks of the studied site.

Trichostomum crispulum Bruch. is an acrocarpusmoss, harvested in a vegetative state, light green to yellowish on surface, brown inside. The leafed stem is 1 to $1.5 \mathrm{~cm}$ long with mucronate acute leaves at the apex and strongly tight in the dry state; they are lanceolate from 3 to $4 \mathrm{~mm}$, very papillose-opaque in the upper $2 / 3$ of the limb. The limbis a little curved at the edges, and terminates in small cap, more or less mucronate, with a vein that is not very excurrente; it has two bands of stereids. Cells in the upper limb have thin membranes and generally square cellular contours becoming rectangular and thick membrane towards the lower part.

\subsection{Phyllum of liverworts (Marchantiophyta)}

4.2.1. Family of Lunulariaceae

Lunularia cruciata (L.) Lindb. (Dichominum cruciatum

(L.) Trevis.; Lunularia cruciata (L.) Dum.;Marchantia 
cruciata L.;Lunularia dillenii Le Jol.; Lunularia michelii Le Jol.; Lunularia vulgaris Raddi illeg.nom.; Lunularia vulgaris Mich.; Marchantia dillenii Le Jolis; Preissia cucullataNees \& Mont.; Staurophora pulchellaWilld. illeg.nom.).

In Morocco, it has been reported on walls, hollows of rocks, embankments, banks of wadis (Corbiere, 19132, Corbiere, 1923a, quoted by Gattefossé \& Werner, 1932); on wet schistose and sandy rocks in the lower valley of Ourika (Mayor, 1924); on old walls in Rabat (BraunBlanquet \& Maire, 1924). It was also observed outside the immediate contact of warm water from the thermal spring of Lalla Aïa (Gattefossé, 1932); on siliceous substrates of Djebel Guedrouz (Werner, 1932, Gattefossé, 1932, Gattefossé \& Werner, 1932); and on limestone rocks (Jovet-Ast, 1956c). Augier (1966), Coudreuse et al. (2005) and Boulay (1984) insist on the wet character of the substrate on which it is observed. It was collectedon rocks and shaded and wet grounds of Chellah.

Lunularia cruciata (L.) Lindb. is a hepatic with thallus of 1.5 to $4 \mathrm{~cm}$ in length and 0.6 to $1.4 \mathrm{~cm}$ in width, dark green in color with crescent-shaped propagule baskets. The thallus is clearly differentiated,intwo parts: that on the dorsal side is formed of a very green assimilative tissue, and that on the ventral side consists of a parenchyma little or not chlorophyllian, being used for retention or conduction of substances. The assimilative tissue is formed by chambers filled with chlorophyllous bristles (sometimes very short), and regularly drawn up on their floor, opening by pores.

\subsubsection{Family of Targioniaceae}

Targionia hypophylla L. (Targionia michelii Corda;Targionia convoluta Lindenb. \& Gottsche;Targionia bifurca Nees \& Mont.;Targionia germanica Corda inval. nom.; Targionia hypophylla var. fimbriata (Müll. Frib.) Müll. Frib.).

In Morocco, it has been reported on fresh rocks (BraunBlanquet \& Wilczek, 1923); Schistose rocks (BraunBlanquet \& Maire, 1924); on the siliceous substrates of Djebel Guedrouz in Haut-Atlas, at $1850 \mathrm{~m}$ a.s.1. (Werner, 1932); as well as along cracks on limestone rocks at Adar-Ouaman in the Anti-Atlas (Mayor \& Werner, 1934). This messicole species according to Augier, 1966, has been described as a pioneer on argillaceoussoil and calcareous sand. According to Boulay, 1984, it is found on clay-sandy soil, on old walls owing to cracks and on limestone rocks. In Chellah, this species was collected on limerubble stone masonry or clay-sandy soil.

Targionia hypophylla L. is a hepatic with a dark green thallus of 10 to $15 \mathrm{~mm}$ long and $4 \mathrm{~mm}$ wide. The thallus is clearly differentiated, in two parts: that on the dorsal side contains a very green assimilative tissue, and that on the ventral side consists of a parenchyma little or not chlorophyllian. The assimilative tissue is formed by chambers filled with chlorophyllous bristles regularly drawn up on their floor, closed or opening by pores. The ventral scales are large, and violet. The stomata are surrounded by 2 to 3 circles of cells very different from the epidermal cells. The capsule located on the ventral surface of the thallus is contained in a bivalve envelope. It contains elaters with 2-3 whorls and spores from 50 to 60 $\mu$ mof diameter.

Targionia lorbeeriana Müller Frib. (Targionia hypophylla var. lorbeeriana (Müll. Frib.) Aleffi \& Schumacker inval.nom.).

In Morocco, it has been reported on calcareous ground and rocks, siliceous ground, granite rocks (Jovet-Ast, 1956c). This species was harvested on limestone rocks in the studied site.

Targionia lorbeeriana Müller Frib., is a hepatic with glaucous thallus with some $4 \mathrm{~mm}$ wide lobes. Thallus is clearly differentiated, on a transverse section, into two parts like the previous species. The oval stomata are surrounded by 1 to 2 rings of about 7 large reniform cells. The capsule located on the ventral surface of the thallus is protected by a bivalve envelope. The spores are about 80 $\mu \mathrm{m}$ in diameter. It organizes dense stands on limestone rocks and between their cracks.

\subsubsection{Family of Ricciaceae}

Riccia crystallina L. emend. Raddi (Riccia crystallina subsp. austrigenaSchiffn.,Riccia crystallina var. major Lindb., Riccia crystallina var. vulgaris Lindenb.)

In Morocco, it has been reported on mud (Corbiere, 1913a, Corbiere, 1913b, quoted by Gattefossé \& Werner, 1932); on calcareous red ground, on ways (Jovet-Ast, 1955, Jelenc, 1955a, 1967, Jovet-Ast, 1965, quoted by Ros et al., 1999); on mud of dried marshes (Augier, 1966, Boulay, 1984, Hamada et al., 2002).

Riccia crystallina L. emend. Raddi, is a hepatic with radial sling thallus, with obtuse lobes, 1 to $4 \mathrm{~mm}$ wide, light green above, pale in lower part. The assimilative tissue is made of lacunary parenchyma. The thallus is one to two times dichotomous. The spores of $70 \mu \mathrm{m}$ diameter on average carry on their convex face a network of alveoli. It is met with Sphaerocarpos michelii forming a same stand.

\subsubsection{Family of Fossombroniaceae}

Fossombronia angulosa (Dicks.) Raddi (Jungermannia angulosa Dicks.).

In Morocco, it has been reported on different substrates: on siliceous soil, on siliceous soil at the edge of a stream; on soil covering rocks of granite, on fresh ground in the shade, on shady rocks partially covered with soil; or on siliceous red soil at the edge of a runoff (Jovet-Ast, 1956c). According to Augier 1966, this species has been reported on non-calcareous wet soil, on the slopes of 
hedges, paths and in rather dry places. It is cosmopolitan in the Mediterranean region according to Boulay, 1984. In Chellah, it is found between the rocks of the studied site. Fossombronia angulosa (Dicks.) Raddi, is a hepatic with leaves of 1-3/0.5 cm with a creeping stem bearing succubus leaves and purple rhizoids. The silk is short with a round capsule containing spores of about $40 \mu \mathrm{m}$. The spore has a hemispherical face and a pyramidal face.

\subsubsection{Family of Sphaerocarpaceae}

\section{Sphaerocarpos michelii Bellardi (Sphaerocarpos} terrestris (Micheli) J.E.Sm.).

It has been reported on soil covering a granite rock (Jovet-Ast, 1956c); on sandy soil and on the granitic rock above the hot spring of Oulmès (Ahayoun et al., 2007). Augier, (1966) describes it as a messicoleand indicates its presence on clay soil. It was harvested on the clay-sandy soil of the studied site.

Sphaerocarpos micheliiBellardi, is a dioecious hepatic with light green thallus with unistratified margins. Antheridia and archegones are located on the dorsal side of the thalli, each is surrounded by an involucre with the pyriform male and the globular female, tightened in the upper part and presenting a small opening. The dehiscence of the capsule is irregular. The spinous spores are united in tetrads of dark brown color measuring approximately $100 \mu \mathrm{m}$ in diameter.

\subsection{Bryophytes and Biodeterioration}

Bryophytes are reviviscent plants that settle as soon as the substrate is moistened (fig. 7 and 8); they can occupy very poor environments in organic matter. The samples were taken at different locations in Chellah site (Fig. 1). The obtained results show that bryophyte colonize both the moistenedsoil, the concrete of steps, the zellij, the terracotta brick made up essentially of calcarenite dating from antique and Islamic times (fig. 9, 10 and 11). This rock was extracted from the quarries of Sidi Bou-Knadel, about ten kilometers to the north of Sale,from plioquaternary age and belonging to the dune cords that extend along the Atlantic coast between El Jadida and Larache. It is a compact, yellow-beige detritic sedimentary rock made up of two detrital fractions: a bioclastic fraction (shell fragments) and a terrigenous fraction composed of millimetric quartz grains bound by a limestone cement.

According to the bioreceptivity criteria described by Guillite (1995), Salé calcarenite offers a set of characteristics favorable to biocolonization. Indeed, the surface quality of Salé calcarenite has a large roughness allowing the anchoring of rhizoids. This surface roughness is also associated with a high porosity of about $24 \%$ and an estimated capillarity of 12.37 (El Amrani El Hassani \& El Azhari, 2009), which is conducive to retention of water and favorable for the installation and growth of bryophytes.

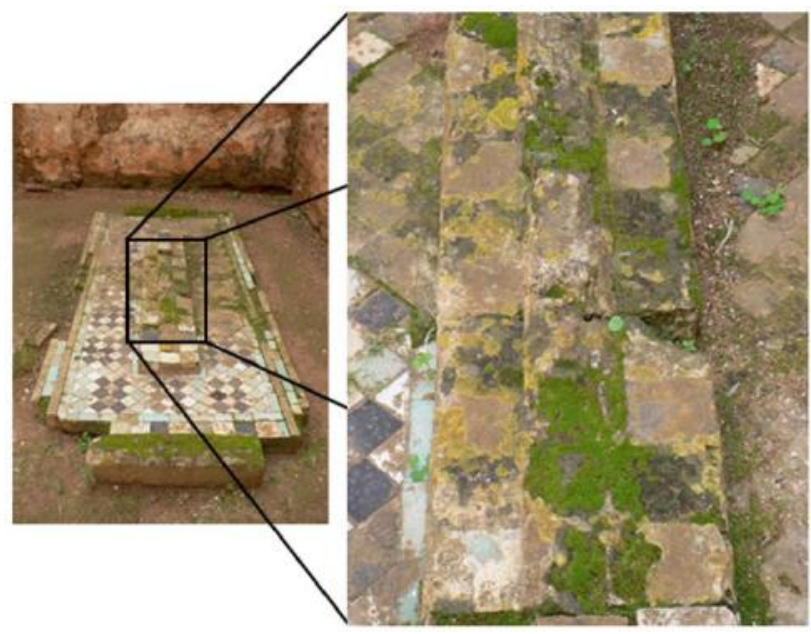

Fig.7: Development of bryophytes on zellij tiles of a tomb in Chellah necropolis contributing to the destruction of the enamel

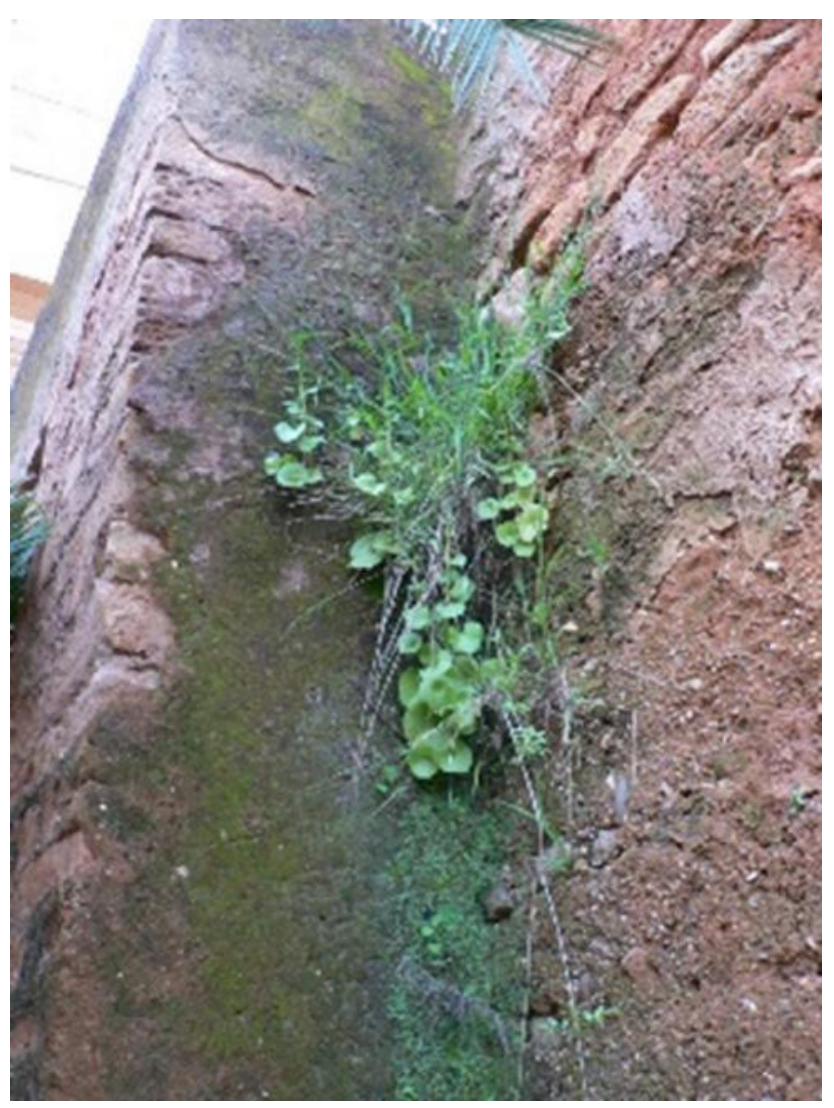

Fig.8: Terracotta brick wall of the gate covered with bryophytes that maintain a high degree of moisture on the masonry 


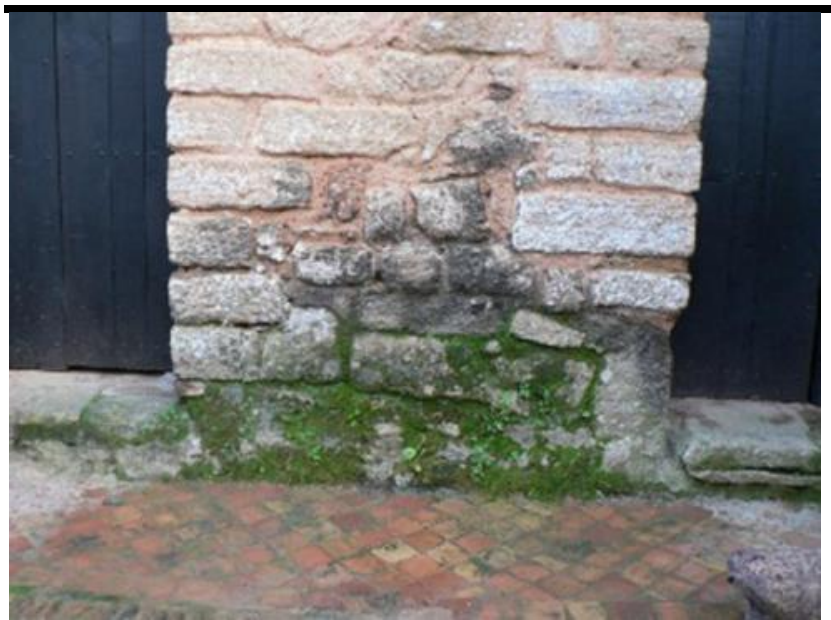

Fig.9: Colonization of the base of a calcarenite wall in Chellah by bryophytes thanks to the capillary rise that favors a high degree of moisture

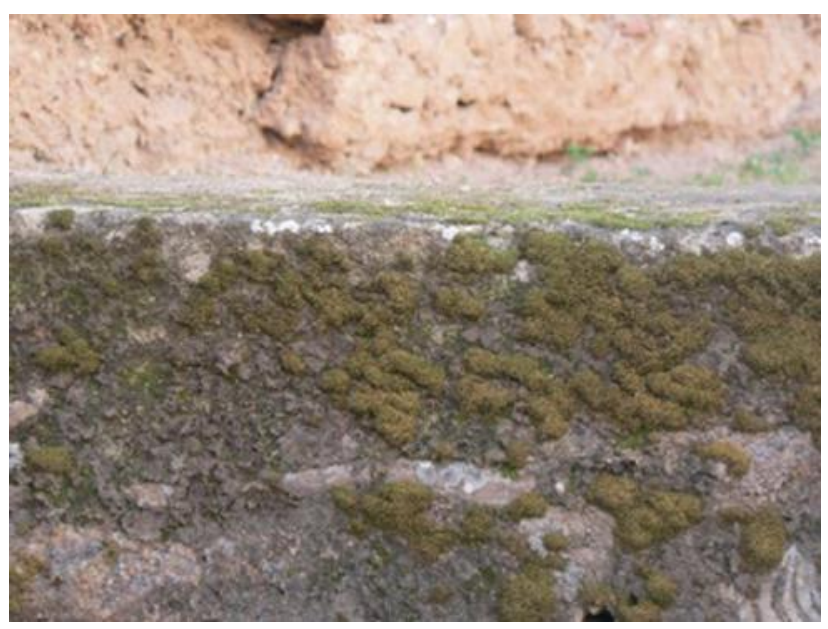

Fig.10: Vertical edge of the calcarenite basin of ablution in Chellah covered by bryophytes

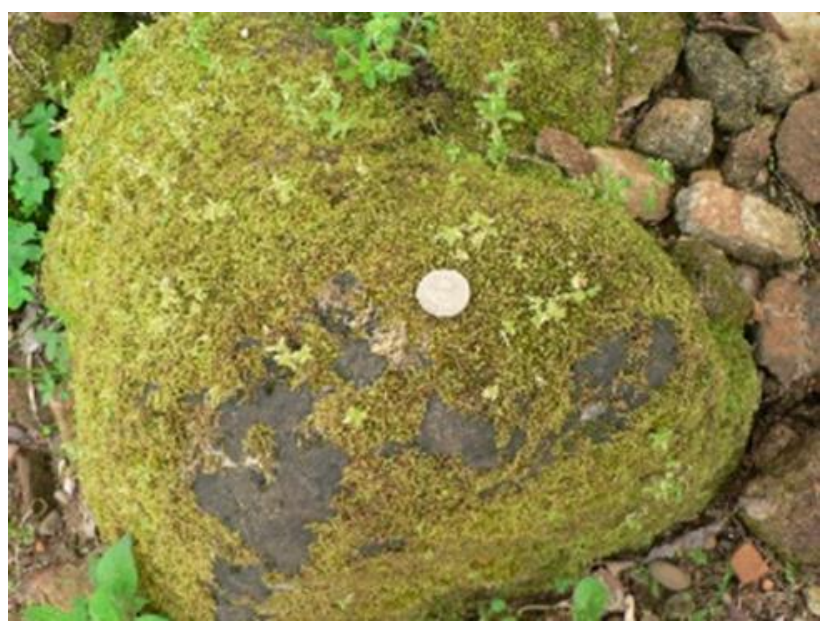

Fig.11: Total recovery by bryophytes of an architectonic element and loss of legibility

Once the supports have been colonized, the bryophytes cause initially a chromatic alteration and thus an aesthetic biodeterioration (Deruelle, 1991; Ortega-Calvo et al.,
1991; Warscheid \& Braams, 2000; Gaylarde et al., 2003; Allsopp et al., 2004).

The bryophyte binding system will develop in the pores of material, exerting pressures inside the structure that may modify the porosity of the support and in the long term to makematerial to burst (Warscheid \& Braams, 2000; Gaylarde et al., 2003). This is called physical biodeterioration.

Other chemical processes are involved: the dissolution of limestone substrate minerals by acidic secretions produced by plants as well as the assimilation of the substrate as a nutrient (Warscheid \& Braams, 2000). This is referred to as a chemical biodeterioration.

\section{CONCLUSION}

The archaeological site of Chellah has been subject to few scientific researches in botanical matter, in particular with regard to the bryophytes. Therefore, our objective consists in describing and identifying the species of bryophytes present in this site and then to establish a list of taxaof these species.

The harvest of the bryophytes allowed us to identify 20 species distributed as follows:

- Fourteen species belonging to the Moss class divided into 5 orders and families and 13 genera, the most widely represented order being the Pottiales with Fissidens bryoides, the most widespread species in the site;

- Six species belonging to the Hepatic class including one leaf hepatic. They are distributed in 3 orders, 5 families and genera, with Lunularia cruciata, the most encountered species.

The colonization of archaeological materials by bryophytes leads to their aesthetic, physical and chemical biodeterioration due to the acid secretions produced by these plants. All these processes have an important role in pedogenesis and thus in the initiation of plant succession. This fact, without gravity in the natural environment, becomes a source of issues when it concerns materials used in historical monuments whose durability is then threatened.

\section{REFERENCES}

[1] Ahayoun K., Ouazzani Touhami A. Benkirane R. \& Douira A. 2013. Catalogue bibliographique des Bryophytes du Maroc (1913-2011). Journal of Animal \& Plant Sciences, 17(1): 2433-2513.

[2] Ahayoun K., Ouazzani Touhami A. \& Douira A. 2007 - Inventaire des Bryophytes de l'Herbier "RAB" de l'Institut Scientifique (Rabat, Maroc), Documents de l'Institut Scientifique, Rabat, (21), p. 71-89. 
[3] Augier J., 1966 - Flore des Bryophytes. Paris, Paul Lechevalier, 702 p.

[4] Basset H. \& Lévi-Provençal E., Chella: une nécropole mérinide, E. Larose éditeur, Paris, 1929.

[5] Basset H. \& Terrasse H., Sanctuaires et forteresses almohades, coll. Hesperis, I.H.E.M., Larose éditeur, Paris, 1932

[6] Benharbit M., «Le site archéologique de Chellah, panorama des facteurs de dégradation », 95p. $1^{\text {ère }}$ édition : juillet 2017. Top Presse Edition-Rabat.

[7] Boube J., « Fouilles archéologiques à Sala : problèmes de la recherche historique au Maroc » dans Hespéris - Tamuda, T. 7, 1966, p. 23-32.

[8] Boulay M. 1904. Muscinées de la France." Deuxième partie" hépatiques. Ed. Paris. $p$ : ILXXXIILXXXVII, 224 p.

[9] Boulay M. 1904. Muscinées de la France." Deuxième partie" Mousses. Ed. Paris. p : ILXXXII-LXXXVII, $623 \mathrm{p}$.

[10] Braun- Blanquet J. 1954 - Contribution à la flore bryologique du Maroc. Revue Bryologique et Lichénologique, XXIII, (1-2), p.100-104.

[11] Braun- Blanquet \& Maire, R. 1924. — Etudes sur la végétation et la flore Marocaines. Mémoires de la Société des Sciences Naturelles du Maroc. NVIII, première partie, p. 160-163.

[12] Braun- Blanquet J. \& Wilczek E. 1923 Contribution à la connaissance de la Flore Marocaine: Liste des Bryophytes récoltés au Maroc au printemps 1921. Bulletin de la Société d'Histoire Naturelle d'Afrique du Nord, 14, (6), p. 225-.226.

[13] Cano M.J., Ros R.M., Gallego M.T., Jime 'Nez J.A. \& Guerra J. - 2002. Contribution to the bryophyte flora of Morocco: the Anti-Atlas catalogue. Cryptogamie, Bryologie, 23: 249-262

[14] Casas C., Brugnès M., Cros R. M., Sérgio C., 2006 Handbook of Mosses of the Iberian Peninsula and the Balearic Islands, Ins d'Estudis Catalanus, Barcelona

[15] Corbiere L., 19131. - Contribution à la flore bryologique du Maroc, d'après les récoltes du Lieutenant Mouret. Revue Bryologique, 40 (1), p. 713.

[16] Corbiere L., 19132 - Nouvelle contribution à la flore bryologique du Maroc d'après les récoltes du Lieutenant Mouret. Revue Bryologique, 40 (4), p. 51 57.

[17] Coudreuse J. et al 2005. Les bryophytes aquatiques et supra aquatiques. Clé d'identification pour la mise en œuvre de l'Indice Biologique Macrophytique en Rivière, 133 p.

[18]Draper I., Lara F., Albertos B., Garilleti R. \& Mazimpaka V. 2006 - Epiphytic bryoflora of the Atlas and Antiatlas Mountains, including a synthesis of the distribution of epiphytic bryophytes in Morocco. Journal of Bryology, 28:312-330.

[19] Frahm J.P. 1988 - Bemerkenswerte Laubmoosfunde aus Nordafrika. Cryptogamie Bryologie, 9 : 231- 234.

[20] Gattefosse J. 1932. - Flore cryptogamique de la source thermale de Lalla Aïa. Bulletin de la Société des Sciences Naturelles du Maroc, XII, (4-6), p. 164167.

[21] Gattefosse J. \& Werner R. G. 1932 - Catalogus Bryophytum Marocanorum Adhuc Cognitorum. Bulletin de la Société des Sciences Naturelles et Physiques du Maroc, XII, (7-8), p. 228-280.

[22] Gattefosse J. \& Werner R. G. 1935 - Contribution à la flore cryptogamique du Maroc (Bryophyta, Algae, Lichenes et Fungi). Bulletin de la Société d'Histoire Naturelles d'Afrique du Nord, 26, (3), p. 72-78.

[23] Hammada S., Dakki M., Ibn Tattou M., Ouyahya A. \& Fennane M. 2002 - Catalogue de la flore des zones humides du Maroc: Bryophytes, Ptéridophytes et spermaphytes. Bulletin de l'Institut Scientifique Rabat section Sciences de la vie, (24), p: 59.

[24] Jahandiez E. 1923 - Contributions à l'étude de la flore du Maroc. Mémoires de la Société des Sciences Naturelles du Maroc, IV, p. 120-122.

[25] Jelenc F. 1955a - Muscinées de l'Afrique du Nord (Algérie, Tunisie, Maroc, Sahara). Société de géographie et d'Archéologie de la province d'Oran, 72, 73, 74, 75, $76: 1-152$.

[26] Jelenc F. 1955b - Contributions à l'étude de la flore et de la végétation bryologiques Nord-Africaines (5ème fascicule). Bulletin de la société d'Histoire Naturelle de l'Afrique du Nord, 46 :107-119.

[27] Jelenc F. 1967 - Muscinées de l'Afrique du Nord (Supplément). Revue Bryologique et Lichénologique, XXXV, (1-4), p. 186-215.

[28] Jiménez J.A., Jiménez J., Ros R. M., Cano M.J. \& Guerra J. 2002b - Contribution to the bryophyte flora of Morocco: terricolous and saxicolous bryophytes of the Jbel Bouhalla. Journal of Bryology, 24: 243-250.

[29] Jovet-Ast S. 1955d. - Hépatiques Marocaines I.Bulletin de la Société des Sciences Naturelles et Physiques du Maroc, XXXV, quatrième trimestre, $\mathrm{p}$. 265-282.

[30] Jovet-Ast S. 1956c. - Hépatiques Marocaines II. Bulletin de la Société des Sciences Naturelleset Physiques du Maroc, XXXVI, premier trimestre, $\mathrm{p}$. 43-60.

[31] Jovet-Ast. S. 1965-Riccia crystalina L. emend. Raddi et Riccia cavernosa Hoffm. emend. Raddi (Notepréliminaire). Revue Bryologique etlichénologique, $33: 459$ - 483. 
[32] Maire R. 1924. — Etudes sur la végétation et la flore du Grand-Atlas et du Moyen Atlas Marocain. Mémoires de la Société des Sciences Naturelles du Maroc. $\mathrm{N}^{\circ}$ VII, p. 137-140.

[33] Maire R. \& Werner R. G. 1934 - Contribution à la flore cryptogamique du Maroc. Bulletin de la Société d'Histoire Naturelles d'Afrique du Nord, 25, (2), p. 40-.60

[34] Meylan CH. 1923 — Listes des Bryophytes récoltés au Maroc au printemps 1921. Bulletin de la Société d'Histoire Naturelle de l'Afrique du Nord, 14, (6), p. 225-226

[35] Nattah I., Ouazzani Touhami A., Benkirane R., Douira A., 2015- Etude des lichens du site de Chellah, monument historique de Rabat, dont Placidium squamulosum (Ach.) Breuss, nouvelle espèce pour la flore lichénique du Maroc, International Journal of Innovation and Scientific Research, Vol. 19, No. 2, pp. 377-401.

[36] Pierrot R.B., 1982. Les bryophytes du Centre Ouest: classification, détermination, répartition. Bulletin de la société botanique du Centre-Ouest, nouvelle série, $\mathrm{N}^{\circ}$ spécial 5, $123 \mathrm{p}$.

[37] Rauh W. 1952- Bemerkenswerte Neufunde von Moosen und Farnen im Hohen Atlas von Marokko. Berichten der Deutschen Botanischen Gesellschaft,65 :79-83.

[38] Ros R. M., Cano M., Munoz J. \& Guerra J. 2000Contribution to the bryophyte flora of Morocco: the Jbel Toubkal. Journal of Bryology, 22: 283-289.

[39] Ros R.M., Cano M.J. \&Guerra J. 1999- Bryophyte checklist of Northern Africa. Journal of Bryology, 21: 207-244.

[40] Ros R.M., Jiménez J.A. \&Cano M.J. 2001Fissidens sublimbatus, new to Morocco and Canary Islands. The Bryologist, 104(3): 468-470.

[41] Ros R.M., Jimenez M.N. \& Guerra J. 1990 - On the chorology, synecology and syntaxonomy of some terricolous bryophytic communities from Northern Africa. Nova Hedwigia , 50: 65- 79.

[42] Smith A.J.E., 2004.The Moss Flora of Britain and Ireland (second edition) Cambridge University Press, 1012 p.

[43] Smith A.J.E., 1990 - The liverworts of Britain and Ireland. Cambridge, Cambridge University press, $362 \mathrm{p}$

[44] Taleb M., Bouhache M., El Mouhadi M., BaghdadB., Molina BallesterosE., Inigo InigoA.C., 2005- Flore nuisible aux monuments historiques du Maroc : cas des villes de Rabat et Salé, X Congrès de la Sociedad Espanola de Malherbologica, 8p.
[45] Werner R. G. 1932 - Contribution à la flore cryptogamique du Maroc. «Bryophyta ». Revue Bryologique et Lichénologique V., (4), p. 223-228. 